Maurice A. Deane School of Law at Hofstra University Scholarly Commons at Hofstra Law

Hofstra Law Faculty Scholarship

2006

\title{
The Principles on Agreements: "Fairness" and International Human Rights Law
}

Barbara J. Stark

Maurice A. Deane School of Law at Hofstra University

Follow this and additional works at: https://scholarlycommons.law.hofstra.edu/faculty_scholarship Part of the Law Commons

\section{Recommended Citation}

Barbara J. Stark, The Principles on Agreements: "Fairness" and International Human Rights Law 392 (2006)

Available at: https://scholarlycommons.law.hofstra.edu/faculty_scholarship/1180

This Book Chapter is brought to you for free and open access by Scholarly Commons at Hofstra Law. It has been accepted for inclusion in Hofstra Law Faculty Scholarship by an authorized administrator of Scholarly Commons at Hofstra Law. For more information, please contact lawcls@hofstra.edu. 


\title{
20 The Principles on Agreements: "Fairness" and International Human Rights Law
}

\author{
Barbara Stark
}

[W]hile most courts still decline to enforce premarital agreements on the same basis as commercial contracts, no consensus emerged on the appropriate rules to apply, much less on the rationale that might be offered to explain them. These questions are the principle topic of this chapter. ${ }^{1}$

Family law is again in turmoil, and the Principles are an ambitious and sometimes inspired effort to increase clarity and fairness. This turmoil can be attributed to two major factors. First, to paraphrase Professor June Carbone, family law is ground zero in the gender wars. ${ }^{2}$ Second, family law is reeling from the upheavals of globalization. These factors provide the backdrop against which the dilemmas addressed in Chapter 7 pertaining to agreements play out.

As the introductory quotation from the PRINCIPLES suggests, Chapter 7 focuses on a particularly intriguing tension between commercial contracts and premarital agreements. This tension is grounded in the broader tension between American views on freedom of contract and autonomy in general, on the one hand, and on freedom of contract and autonomy in the specific context of the family, on the other. While the emphasis on freedom of contract may be peculiarly American, tension between legal regimes and private contractual regimes governing the family is quite common from an international perspective. As it is in the United States, the tension between competing regimes in other countries reflects deep cultural tensions. Rather than being grounded in the sacrosanct principles of auton* omy and contractual freedom, however, private contractual regimes in other countries are generally grounded in religious or customary practices. ${ }^{3}$ Prominent examples include the Islamic and Jewish marriage contracts ${ }_{*}^{4}$

While these tensions have been addressed by a broad range of domestic courts relying on domestic law, here and abroad, ${ }^{5}$ this chapter focuses on the mediation of these competing

\footnotetext{
${ }^{1}$ PRINCIPLES $\$ 7.01 \mathrm{cmt}$, a, at 947.

${ }^{2}$ See June Carbone, Has the Gender Divide Become Unbridgeable: The Implications for Social Equality, 5 J. Genden RACE \& JUSr. 31, 52 (2001) ("Custody is ground zero in the gender wars,").

${ }^{3}$ Courtney W. Howland, The Challenge of Religious Fundamentalism to the Liberty and Equality Rights of Women: An Analysis Under the United Nations Charter, 35 Colum. I. Transwar'L L. 271, 283-85 (1997) (explaining how religious fundamentalist laws require the obedience of women, contrary to the UN. Charter norms of equality); Symposium, Roman Catholic, Islamic, and Jewish Treatment of Familial Issues, including Education, Abortion, In Vitro Fertilization, Prenuptial Agreements, Contraception, and Marital Fraud, 16 Lox. L.A. INT'L \& Comp. L. REv, 9 , $60-74$ (1993) (setting out religious perspectives on prenuptial agreements).

${ }^{4}$ Dawoud Sudor El Alam, Thb Marriage Contract in Islamic Law (1992).

${ }^{5}$ Ann Laquer Estin, Toward a Multicultural Family Law, 38 FAM. L.Q. 59 (2004).
} 
interests under international law. International law addresses these conflicțs through private international law, such as the Convention on the Recognition of Foreign Judgments, ${ }^{6}$ and through public international law, specifically international human rights law. ${ }^{7}$ This chapter argues that the PRINCIPLES' treatment of agreements should incorporate, and be subject to, the relevant human rights law.

While there are certainly good reasons for incorporating human, rights law in all areas of family law $\mathrm{w}_{\mathrm{r}}$ there are especially strong reasons for adopting it here. First, any, consensus regarding "appropriate rules" must be grounded in a coherent rationale "Because of the stature of the norms to which they are an exception, including constitutionally-protected religious freedoms, the underlying rationale to justify different treatment between marital and nonmarital contracts should be grounded in law of commensurate stature. Second, because of the growing diversity of the, American population, and the proliferation .of different cultural norms, that law should not be grounded in the amorphous and irrelevant conceptions of equity, but in well-established and widely, accepted international human rights law. To the extent that the Principles already incorporate that law, albeit tacitly, they represent an important step forward. To the extent that the Principles function in a legal context in which that law is ignored, however, vital interests - recognized in the rest of the world as "rights." - remain at risk.

Part I of this chapter first explains the need for a more robust rationale for deciding which agreements to enforce. Second, it explains why such a rationale is appropriately grounded in international human rights law. Finally, it explains how the goals of the PRINCIPLES with respect to agreements would be furthered by the explicit incorporation of international human rights law. Part II compares and contrasts the treatment under the Principles of private contractual regimes, including religious or customary regimes, with the treatment of such regimes under the Convention on the Elimination of All Forms of Discrimination Against Women ("Women's Convention")..$^{8}$ Part III compares the treatment of these regimes under the PRINCIPLEs with their treatment under the International Covenant.on Economic, Social, and Cultural Rights, ("Econqmic Covenant"). ${ }^{9}$ This chapter concludes that although international human rights law is hardly a panacea, ${ }^{10}$ its incorporation into the law of agreements would promote the development of U.S. law and extend the influence of that law abroad, at least in this particular context.

\section{Why the Principles Need Human Rights Laws}

\section{A. The Need for a More Robust Rationale}

As Professor Ira Ellman, the primary drafter of the Principles, explains, the drafters "bit the bullet" to adopt certain rules in order to create clearer, better boundaries for

${ }^{6}$ Concluded 1 Feb."1971; entered into force 20 Aug. 1979 available at http://www.hcch.net/index_en.php? act $=$ conventions.text \& $x i d=78$ (last visited October 29,2005 ).

${ }^{7}$ See Part IV, infra.

${ }^{8}$ Convention on the Elimination of All Forms of Discrimination Against Women, G.A. Res. 180, 34 U.N. GAOR, 2 d. Sess., Supp. No. 21, at 889, U.N. Doc. A/34/46 (1981) (hereinafter Women's Convention).

9 International Covenant on Economic, Social and Cultural Rights, opened for signature Dec. 16, 1966, 993 U.N.T.S. 3 (hereinafter Economic Covenant).

${ }^{10}$ See generally MARY ANN GLENDON, Rights TALK (1991) (describing over-reliance on, and degradation of, "rights talk"). In a recent work, Professor Glendon has affirmed the continuing importance of human rights. See MARY ANN Glendon, A World Made New: Eleanor Roosevelt and the Universal Declaration of Human Rights (2001) (describing the compassion and determination of the early human rights movement). 
family lawyers and family law courts: "Fairness concerns set boundaries around our choice[s].... The problem is that those boundaries are very wide."11 As Professor Ellman concedes, however, these boundaries are very rough and somewhat arbitrary. Another choice is at least as fair.

There are two important justifications for circumscribing the ability of parties to enter into family law agreements, according to the Principles. First, there are limits on the "cognitive capacity"12 of those likely to enter into family contracts; namely, they are typically in love and unreasonably optimistic about the likelihood of their marriage enduring. Second, public policies, especially those that protect children and spouses left vulnerable after long marriages, are apt to be abrogated. ${ }^{13}$

These rationales for limiting agreements are necessary, but not sufficient. First, as noted above, the fairness parameters within which they function are so broad, and so loose, that they provide little real guidance for deeision makers. Equally important, the minimal guidance they do provide assumes that the status quo is "fair;" it assumes that men and women entering into marriage or domestic partnerships are on a level playing field. This normalizes and perpetuates existing inequalities.

Neither of these flaws is likely to be corrected by the minimal limits on agreements imposed by the Principles. Assuming procedural fairness, agreements may be put aside only if they are "unconscionable" as understood in the law of contracts. This explicitly includes "substantive unconscionability, or a gross one-sidedness in terms." ${ }^{14}$ Further, under Section 7.05, the parties may be relieved of their obligations under the agreement, when' enforcement "would work a substantial injustice." ${ }^{15}$ Such a finding, however, is only possible under three specific circumstances: where 1) "more than a fixed number of years have passed," 2) the couple has had a child, or 3) there has been an unanticipated change of circumstances. ${ }^{16}$ As Professor Ellman summarizes, "[H]opefully law can provide remedie's that correct gross injustices..." ${ }^{17}$ The law is more likely to do so, however, where it provides frameworks for identifying such "gross injustices." Such frameworks, conspicuously lacking in the PRINCIPLES, may be found in international human rights law.

Moreover, as determined under the Principles, "fairness" often depends on implied bad faith. In both the "Carol and Doug" and the "Bugfree Software" illustrations, ${ }^{19}$ for example, one spouse pressures the other into entering into an agreement granting significant benefits to the pressuring spouse, who is planning to leave the unsuspecting partner. What if Carol has no old boyfriend waiting in the wings, but has simply grown tired of being a doctor's wife? What if the waiver by the nonprogrammer spouse in the software illustration was insisted upon by the programmer's business partner, whose own marriage was in trouble and who was concerned about family court interference in the business? In both instances, the result is the same - the unsuspecting partner gives us statutory benefits but there is no bad faith. "Fairness," as the PRINCIPLEs acknowledge, may be in the eye of the beholder.

A more robust rationale is needed, especially to counter constitutionally-protected freedom of religion and norms, such as freedom of contract, to which courts have historically deferred. In the United States, religious freedom is expressly protected under the

\footnotetext{
11 Ira Ellman, Why Making Family Law is Hard, 35 ARIz. ST. L.J. 699, 701-02, 707 (2003).

12 Principles $\$ 7.05 \mathrm{cmt}$ b, at 985-8. $\quad{ }^{3}$ Principles $\$ 7.05 \mathrm{cmt}$. c, at $990-91$.

${ }^{14}$ Principles $\$ 7.01 \mathrm{cmt}$. e, at $948 . \quad{ }^{15}$ Principles $\$ 7.05(1)(\mathrm{b})$.

${ }^{16}$ Principles $\$ 7.05(2)$ (a).

${ }^{18}$ Principtes $\$ 7.01$, illus. 3 , at $950-51$.

${ }^{17}$ Ellman, supra note 11 , at 707 .

19 Principles $\$ 7.01$, illus. 2 , at 949.
} 
Establishment Clause of First Amendment, which assures the separation of church and State. ${ }^{20}$ The question whether religious marriage contracts can be enforced by secular courts without violating this principle, however, has been a contentious one. Some courts have held that a State would be impermissibly promoting religion to enforce such contracts. ${ }^{21}$ Others have found ways to circumvent such changes. ${ }^{22}$

In many other countries, however, such circumvention is unnecessary because there are no bars to enforcement of religious agreements. Indeed, in some States, ${ }^{23}{ }^{2}$ such'as Israel and Kenya, responsibility for at least some areas of family law has been explicitly delegated to religious authorities. ${ }^{24}$. Religious agreements, accordingly, are recognized and enforceable. The question thus becomes whether a particular marriage contract, clearly implicating the right to practice one's religion, is in conflict with other, equally clear, human rights norms, such as the norm against nondiscrimination.

The right to: religious freedom is not as well developed in international law as. some other human rights. In fact, although the U.N. General Assembly adopted a Declaration on the Elimination of All Forms of Intolerance and of Discrimination Based on Religious Belief without:a. vote on November $25,1981,{ }^{25}$ no legally-binding convention has yet come into force on the subject. Nevertheless, the prohibition against discrimination on the basis of.religion is well-established. ${ }^{26}$ By identifying competing human rights norms of comparable stature, international human rights law directly confronts the dilemma of competing rights. This has produced rigorous and useful frames of analysis, such as that proposed by Donna Sullivan to resolve competing claims between gender equality and religious freedom. ${ }^{27}$

Sullivan begins by observing that the peremptory norms of human rights law, including norms against genocide, slavery, and torture, clearly trump claims of religious freedom. Thus, she argues, the Hindu practice of burning a widow on her husband's funeral pyre cannot be sanctioned. Where there are no peremptory norms at stake, she urges a balancing test, focusing on the relative importance of the competing rights in the particular context. Specifically, she asks how important the particular right is in terms of the "overarching goal of gender equality." 28 Second, she asks how important the particular religious practice

${ }^{20}$ U.S. Const. amend. I.

${ }^{21}$ See Aflalo v. Aflalo, 685 A.2d 523 (N.J. Super. Ct. Ch. Div. 1996) (refusing to enforce agreement because order requiring husband to give wife a get, which is a religious divorce, would violate his first amendment rights). See also, e.g., Kaddoura v. Hammound 168 D.L.R. 4th 503 (1998) (refusing to enforce terms of Muslim marriage certificate). See generally Rostain, Permissible Accommodations of Religion: Reconsidering the New York Get Statute, 96 Yale L.J. 1147 (1987).

${ }^{22}$ See, e.g., Goldman v. Goldman, 554 N.E.2d 1016 (Ill. App. Ct. 1990) (requiring husband to provide get).

${ }^{23}$ In this chapter, "state" refers to a constituent unit of a federal entity, such as New York, while "State" refers to a nation state, such as China.

24 Barbara Stark, International Family LaW: AN INTroduction 126 (2004) (describing five separate family law systems in Kenya, three of which are religious); Frances Raday, Israel - The Incorporation of Religious Patriarchy in a Modern State, in Gender Bias and Family Law Comparative Perspectives 209 (Barbara Stark ed., 1992) (describing the role of religion in Israeli Family Law).

${ }^{25}$ G.A. Res. 36/55, 36 U.N. GAOR, Supp. No. 51 (1981), U.N. Doc. A/36/684 (1981).

${ }^{26}$ Such discrimination is explicitly prohibited in Article 2 of the Universal Declaration of Human Rights, G.A. Res. 217A, U.N. GAOR, 3d Sess., Supp. No. 3, at 572, 575, U.N. Doc. A. 810 (1948) (hereinafter "Universal Declaration"); Article 2.2 of the Economic Covenant, supra note 9; Article 2.1 of the International Covenant on Civil and Political Rights, entered into force March 23, 1976, art. 2.1, 999 U.N.T.S. 171.

27 Donna J. Sullivan, Gender Equality and Religious Freedom: Toward a Framework for Conflict Resolution, 24 N.Y.U. J. INT'L. L. \& Pol. 795 (1992).

${ }^{28} \mathrm{Id}$. 
at issue is to the right of religious freedom..$^{29}$ Additional factors include the cumulative impact of each upon the other and, once it has been determined that a restriction on the religious practice is appropriate, an assessment of the proportionality of the restriction.

The explicit adoption of human rights norms could similarly clarify the debate'about private agreements in the PrINCIPLEs. Freedom of contract is not specifically addressed in the U.S. Constitution. However, as constitutional law expert Professor Norman Dorsen and his coauthors explain in their book Comparative Constitutionalism, the privileged place of freedom of contract in American jurisprudence has largely remained unchallenged: "[I]n the liberal economies of the nineteenth century, contractual freedom was uncontested."30 This extreme deference to the principle of freedom of contract was not seriously challenged until the Great Depression. ${ }^{31}$ The desperate plight of millions of Americans simply made it untenable to maintain freedom of contract as a paramount norm.

The same concern that justified abrogation of freedom of contract there, the need to protect the vulnerable, is applicable here. Concern for the vulnerable is particularly important where, as here, the vulnerable are least likely to protect themselves. As noted above, they are unlikely to do so for several reasons, including the social expectations of the parties and the typical assumption (especially, perhaps, among those who have not previously been divorced) that the marriage will endure. These reasons have historically led courts to treat contracts in family law differently. ${ }^{32}$. The PrINCLPLES treat family contracts more dike commercial contracts, to the detriment of the most vulnerable. Incorporation of human rights norms would restore historical protections, but only for those whose human rights were actually violated by privileging autonomy in this context.

\section{B. Why Look to International Human Rights Law}

The PRINCiples should look to international human rights law because it offers a normative framework for an increasingly multicultural America in an increasingly globalized world. Globalization is transforming family law. As the United Nations notes, families are the primary unit of social organization, ${ }^{33}$ and families are changing, trying to adapt to new demands and taking advantage of new mobility. Women seek new lives in arranged marriages or as "mail order brides." They also seek asylum as refugees, fleeing domestic violence. Workers follow jobs, leaving their families behind and sometimes starting new families in their new countries. Child abduction has become a growing threat as parents of different nationalities divorce, and both want their children to be raised in their own national traditions.

Even as ties to such traditions become increasinglyattenuated, their appeal may become stronger for some. Local religious leaders may insist on even stricter adherence to local customs, especially those related to marriage, divorce, and the care and custody of children, as their authority is challenged by competing customs and international norms. In many

${ }^{29} \mathrm{Id}$.

${ }^{30}$ Norman Dorsen et AL, Comparative Constitutionalism 1191 (2003). As I have explained elsewhere, it was not necessary to include the right to property in the Bill of Rights because it was not only implicit, but privileged. See Barbara Stark, Deconstructing the Framers' Right to Property: Liberty's Daughters and Economic Rights, 28 HoFsTRA L. REv. 963 (2000). Freedom of contract, specifically the right to enter into binding agreements regarding one's property, was similarly privileged.

${ }^{31}$ DoRsen ET AL, supra note 36.

${ }^{32}$ See generally Brian Bix, this volume.

${ }^{33}$ See infra notes 37, 46 (discussing the Universal Declaration of Human Rights and the Economic Covenant). 
States, such as Saudi Arabia, family law is basically left to religious authorities. This reflects both its relatively low importance to national governments, compared to matters of trade and finance, for example, and its paradoxically high importance to those who seek to shape the national identity. As Article 9 of the Basic Law of Saudi Arabia states, "The family is the kernel of Saudi society, and its members shall be brought up on the basis of Islamic faith." ${ }^{34}$ There are powerful trends and countertrends everywhere, and competing norms of family law are at the heart of each. The impact of this on family law practice has been noted by family law practitioners. ${ }^{35}$ Family law is no longer limited by national boundaries. Indeed, starting with the first paragraph of the Chief Reporter's Foreword, ${ }^{36}$ references to foreign law pervade the PrINCIPLEs. The explicit incorporation of international human rights law would be a natural next step.

Human rights law represents a rough consensus among divergent national systems. More than 180 States have ratified the Civil Covenant, the Economic Covenant, the Women's Convention and the Convention on the Rights of the Child. ${ }^{37}$ By incorporating human rights law, domestic law accedes to an international bottom line. Domestic law incorporating human rights norms accordingly is likely to be compatible with a broad range of foreign law that also incorporates these norms. As a corollary, it is increasingly likely to resonate with an increasingly mobile population.

Human rights law is grounded in the Universal Declaration of Human Rights ("Universal Declaration") drafted in $1948 .{ }^{38}$ Under the Universal Declaration, parties recognized that "[ $t]$ he family is the natural and fundamental group unit of society and is entitled to protection by society and the State." 39 The Universal Declaration was merely aspirational, however; the parties did not intend it to be legally binding. ${ }^{40}$ Rather, it was expected that a binding convention would be drafted in due course. ${ }^{41}$ Because of the East/West split, and the emerging consensus that different kinds of rights could be better implemented by different mechanisms, two international treaties followed instead of one legally binding convention. The rights and obligations set out in the Universal Declaration were defired with greater specificity in the legally-binding Economic Covenant and International Covenant on Civil and Political Rights ("Civil Covenant"). ${ }^{42}$ Together with the Universal Declaration, these definitions comprise the'International Bill of Rights.

There is some overlap between the two covenants. For example, Article 23 of the Civil Covenant expressly reiterates the State's obligation to protect the family as "the natural

34 Barbara Stark, International Famiuy Law: An Introduction 2 (2004).

35 The ABA Section on Family Law has recently devoted an entire issue to the subject. See The Impact of Diverse Cultures on Family Law, 27 FAM. Advocate (Fall 2004) (introducing range of topics confronting family lawyers).

${ }^{36}$ Principles, Foreword at xvii ("One expects a nation's family law to reflect its cultural values. In America, those cultural.values include a strong tradition of family privacy, with both common-law and constitutional roots. French laws, bars parents from giving their child a name, that does not appear on a government-approved list. Mexican family courts are empowered to settle disputes between spouses about their respective employment.").

${ }^{37}$ Louis Henkin et al., Basic Document Supplement to International LaW Cases and Materials 151, 146, 174, 188 (3rd ed. 1993). In 1948, when the Universal Declaration was adopted, only 56 countries were parties. Forty-eight countries voted in favor of the Universal Declaration, none opposed and eight abstained. Id. at 143. The Child's Convention has been ratified by 192 countries, available at http://www.unhchr.ch $/ \mathrm{html} / \mathrm{menu} 3 / \mathrm{b} / \mathrm{k} 2 \mathrm{crc} . \mathrm{htm}$ (last visited October 29, 2005).

${ }^{38}$ See Universal Declaration, supra note $26 . \quad 39$ Id. at art. 16.3.

${ }^{40}$ Many argue that certain provisions in the Universal Declaration have since become binding as a matter of customary international law. HENKIN ET AL., supra note 37, at 322.

${ }^{41}$ Barbara Stark, United States Ratification of the Other Half of the International Bill of Rights, in HuMAN RugHTS IN THE UNited States: Looking InWard and Outward 75 (David Forsythe ed., 2000).

${ }^{42}$ Civil Covenant, supra note 26. 
and fundamental group unit of society"43 as set out in the Universal Declaration. ${ }^{44}$ Article 10 of the Economic Covenant similarly provides that " $\mathrm{t}]$ he widest possible protection and assistance should be accorded to the family, which is the natural and fundamental group unit of society, particularly for its establishment and while it is responsible for the care and education of dependent children." 45 This arguably requires the State to enact laws protecting vulnerable parties, especially women and children, upon dissolution of marriage.

For the most part, however, the Civil Covenant addresses negative obligations of the State; it imposes limits on State interference with individuals. The Economic Covenant, in contrast, basically addresses affirmative obligations of the State, including the provision of welfare and social security benefits. The Economic Covenant requires the State to affirmatively assure its people an adequate standard of living, healthcare, education, and employment. In Article 10 of the Economic Covenant, for example, the State recognizes that mothers are entitled to "special protection" before and after childbirth, including paid leave. Thus, a State party would be required to incorporate into domestic law either welfare provisions assuring compensation or a requirement that private employers do so.

There are two obvious obstacles to the incorporation of international human rights law in the PRINCIPLES. First, the United States is not a party to the Economic Covenant or the Women's Convention, although it has signed both. ${ }^{46}$ Second, human rights law historically focuses on the individual's rights vis-á-vis the State, that is, the State's treatment of its people, rather than individuals' obligations to each other. Indeed, the State's interference with those obligations has historically been rejected on the ground that the State is violating family privacy. ${ }^{47}$

The U.S. failure to ratify the human rights conventions does not preclude their incorporation here. International human rights norms have been used in a broad range of contexts to provide normative guidance $\rightarrow$ from adoption by municipalities, such as San Francisco, and states, such as Massachusetts, to signal support for human rights, ${ }^{48}$ to the adoption by multinational corporations of Model Codes of Conduct, both to signal support for human rights and, it has been suggested, to preempt binding regulation. Even if particular human rights instruments are not ratified or acceded to by a particular country, in short they may be relied upon as nonbinding "soft law." The Sullivan Principles in South Africa are a well-known example of the use of soft law to promote human rights. ${ }^{49}$

\section{Human Rights Law Would Further the Goals of the PrincIPLES}

The explicit incorporation of international human rights would create clearer, better boundaries for family lawyers and courts. This is supported by two distinct but converging trends: first, the increasing receptivity of U.S. courts to human rights in general,

${ }^{43}$ See Universal Declaration, supra note 26, at art. 16.3.

${ }^{44}$ Article 16.3 of the Universal Declaration provides, "The family is the natural and fundamental group unit of society and is entitled to protection by the society and the State."

${ }^{45}$ Economic Covenant, supra note 9, at 7.

${ }^{46}$ President Jimmy Carter signed the Economic Covenant and the Women's Convention. Neither of these has been ratified by the Senate, however. HENKIN ET AL, supra note 37, at 784 .

${ }^{47}$ See, e.g., Kilgrow v. Kilgrow, 107 So.2d 885 (Ala. 1958).

${ }^{48}$ See Crosby v. National Foreign Trade Council, 530 U.S. 363 (2000) (holding Massachusetts law barring trade with Burma because of human rights violations invalid under the Supremacy Clause).

${ }^{49}$ See generally SANCTIONS AGA 7 NST APARTHEID (Mark Orkin ed. 1989). The Sullivan Principles challenged apartheid in South Africa. 
and second, the increasing application of human rights norms to family law issues, by human rights bodies as well as domestic courts throughout the world.

The new openness of United States' courts to human rights is shown in two recent Supreme Court decisions. In Grutter v. Bollinger, ${ }^{50}$ the United States Supreme Court upheld the affirmative action program at the University of Michigan Law School. Justice Ginsburg, joined by Justice Breyer, began her concurring opinion by setting out "the international understanding of [the office of] affirmative action"51 in the International Covenant on the Elimination of All Forms of Racial Discrimination, ${ }^{52}$ to which the United States is a party, and the Women's Convention, to which the United States is a signatory. In Lawrence v. Texas, ${ }^{53}$ which struck a Texas sodomy statute, the Court again cited an international human rights instrument. The majority explicitly referred to the European Convention for the Protection of Human Rights and Fundamental Freedoms, for the proposition that homosexual activity should not be criminalized. ${ }^{54}$ At least some members of the Court are showing what Justice Blackmun, citing the Declaration' of Independence, referred to as a "decent respect to the opinions of mankind." ${ }^{25}$ Lawrence also shows the Court's recognition that human rights norms are pertinent to intimate relationships, which have historically been the province of family law.

The Lawrence decision is consistent with, and may be understood as a part of, the increasingly frequent application of human rights norms to family law issues throughout the world. Examples range from the requiręment that Ireland permit the dissemination of information about abortion pursuant to the European Convention on Human Rights to the procedural safeguards to protect surrendering parents in international adoptions under the Convention on Intercountry Adoption. ${ }^{56}$ In some cases, international human rights support domestic law, such as the UNICEF Report on Child Marriage, ${ }^{57}$ which strongly affirms Indiạ's Child Marriage Restraint Act of $1929 .^{58}$ In other cases, human rights norms serve as a counterweight to local law. In Kenya, for example, customary law regarding marital property leaves Kenyan women destitute and without recourse at divorce, in violation of the Women's Convention. ${ }^{59}$

Indeed, it can be argued that the incorporation of these norms is particularly important in the instant context precisely because of the U.S. failure to ratify the three human rights conventions, which has created an unfortunate and anomalous lacuna in American family law. As human rights and family law scholars have pointed out, ${ }^{60}$ international human rights law has already had a major impact on family law. The incursion of the State into the traditionally private sphere of the family, for example, has been justified on the grounds

${ }^{50} 539$ U.S. 306, 342 (2003).

51 Id. at 342.

${ }^{52}$ International Covenant on the Elimination of All Forms of Racial Discrimination, entered into force Jan. 4, 1969, 660 U.N.T.S. 195.

53539 U.S. 558 (2003).

${ }^{54}$ See id. (citing European Convention for the Protection of Human Rights and Fundamental Freedoms, entered into force Sept. 3, 1953, 213 U.N.T.S. 22).

${ }^{55}$ Harry A. Blackmun, The Supreme Court and the Law of Nations: Owing a Decent Respect to the Opinions of Mankind, 88 Aм. Soc'y INT'L L. Proc. 383 (1994). Others, notably Justice Scalia, remain more parochial. In a recent case, Justice Scalia dismissed evidence of the rejection of the death penalty throughout the western world, explaining that the court should only be concerned with American values.

${ }^{56}$ STARK, supra note 24 , at 51-60, 163.

${ }^{57}$ UNICEF, Early Marriage Child Spouses, March 2001 (available at http://www.unicef-icdc.org/publications/ pdf/digest7e.pdf) (last visited October 29, 2005).

58 STARK, supra note 24 , at 16.

${ }^{59} \mathrm{Id}$. at 59-60 (discussing work of Human Rights Watch).

${ }^{60}$ Berta Hernandez-Truyol, Asking the Family Question, 38 FAM. L.Q. 481 (2004); Estin, supra note 5. 
of the significant human rights at stake. Professor Ellman's examples of such incursions domestic violence, abortion, and same-sex relationships ${ }^{61}$ - have all been recognized and championed as human rights issues.

In addition, the goals of the PrincipLes with respect to agreements would be furthered by the incorporation of international human rights law in at least three important ways. First, human rights law provides'normative support for the recognition of gay and lesbian relationships explicitly recognized in the Principles ${ }^{62}$ Second, recognition of human rights law would promote increased American patticipation in private international law regimes that incorporate human rights norms, such as the pending Convention on Maintenance. ${ }^{63}$ Third, recognition of humán rights law by American courts would encourage greater respect for the decisions of American courts.by foreign courts.

\section{The Principles and the Women's Convention}

\section{A. Why the Women's Convention?}

The tension between American views on freedom of contract and autonomy in general, on the one hand, and American views on freedom of contract and autonomy in the specific context of the family, on the other, is grounded in the historical view of the family as a protected zone. In this view, ordinary rules can and should be suspended for the benefit of vulnerable family members, particularly women and children. This historical truism has been challenged, however, by a broad range of theoretical arguments as well as practical developments. Some claim marital regimes do not in fact protect the vulnerable members of the family; rather, they perpetuate traditional patterns of domination and subordination. ${ }^{64}$ Others suggest that protection is no longer necessary ${ }^{65}$ Finally, the case has been made that the fundamental structure of family law itself is not only gendered, but bad for women. ${ }^{66}$

Whether contractual regimes are better or worse than marital regimes is similarly debated. As many commentators have observed; the religious authority for contractual family régimes is often profoundly 'gendered, especially where such authority is shaped by patriarchal cultural norms. ${ }^{67}$ It has similarly been argued that despite their ostensible neutrality, freedom of contract and autonomy are also gendered ${ }^{68}$. While the precise ways in which family law is gendered, and the extent to which anyone benefits, are contested, it is clear that family law affects men and women differently.

${ }^{61}$ Ellman, supra note 11, at 701-02.

62 Same-sex relationships are encompassed by the PRINCIPLEs' domestic partnership proposals and by the provisions governing agreements to the extent that the parties deviate from the legal default by agreement.

${ }^{63}$ STARK, supra note 24 , at 118-21.

${ }^{64}$ Catharine A. MacKinnon, Feminism Unmodipied 32-45 (1987)

${ }^{65}$ See, e.g. Orr v. Orr, 440 U.S. 268 (1979) (rejecting "old notion" that the man was responsible for providing a home as gender discrimination). But see, Donald G. McNeil Jr., Real Men Don't Clean Bathrooms, N.Y. Tımes, Sept. 19, $2004 \$ 4,1$ (summarizing recent report of Bureau of Labor Statistics, documenting persistence of gendered division of labor).

${ }^{66}$ Martha Fineman, Thb Neutered Mother and Othar Tragedies of the Twentieth Century (1995); Frances E. Olsen, The Family and the Market: A Study of Ideology and Legal Reform, 96 HARv. L. Rkv. 1497 (1983).

${ }^{67}$ See, e.g., Is Multiculturalism BAD for Women? (Joshua Cohen et al. eds. 1999); Raday, supra note 24; MERLE Weiner \& Marianne Blair, Family in the World Community (2003); Family Law and Gender Bias: ComParatrve Perspectives (Barbara Stark ed. 1992).

${ }^{68}$ Linda McClain, "Atomistic Man" Revisited: Liberalism, Connection, and Feminist Jurisprudence, 65 S. CAL. L. Rev. 1171 (1992); Clare Dalton, An Essay in the Deconstruction of Contract Doctrine, 94 YALE L.J. 997 (1985). 
The underlying premise here is that, as Aristotle explained, it is just as unfair to treat people who are not similarly situated the same, as it is to treat those who are similarly situated differently. ${ }^{69}$ Another premise here is that "gender-related behaviors are a process of individual and social construction." ${ }^{30}$ Incorporation of the Women's Convention is simply a mechanism by which to recognize the ongoing gender discrimination in the marketplace and civil society and the ways in which such discrimination operates to delegate private sphere responsibilities to women, ${ }^{71}$ especially when they are mothers. ${ }^{72}$ The male partner, who has enjoyed some of the benefits of this discrimination, should in fairness assume some of the costs.

Two examples of this ongoing gender discrimination are: 1) domestic violence and 2) the persistence of a gendered wage gap. No data are available regarding domestic violence or the persistence of a gendered wage gap among the concededly small, self-selected portion of the population affected by the PrINCIPLEs' provisions governing agreements. No empirical studies have focused on the incidence or severity of either among those who enter into premarital or marital agreements. But the prevalence of both domestic violence and a gendered wage gap in the general population makes it reasonable to expect to encounter both in this context as well. This is especially likely when considering particular segments of the population' likely to enter into such agreements, such as mail-order brides or young women entering into marriages arranged by their families, in which the wife is especially likely to be younger, poorer, and less well-educated than her husband. ${ }^{73}$

\section{Domestic Violence}

As Professor David Westfall argues in this volume, there are many good reasons for taking domestic violence into account at divorce. ${ }^{74}$ Under the ALI's framework in Chapter 7,

69 Joan Williams, Unbending Gendder: Why Family And Work Conflict and What To Do About It 205 (2000). Seegenerally, Christine A. Littletón, Reconstructing Sexual Equality, 75 CAL. L. Rev. 1279, 1296 (1987) (“[Acceptance] asserts that eliminating the unequal consequences of sex differences is more important than ... trying to eliminate them altogether.").

${ }^{70}$ Kay Deaux \& Brenda Major, A. Social-Psychological Model of Gender, in Theoretical Perspectrves on Sexual Difference 91(Deborah L. Rhode ed. 1979).

${ }^{71}$ Amy Wax, Bargaining in the Shadow of the Market: Is There a Future for Egalitarian Marriage? 84 VA. L. REv. 509, 513 (1998) ("Although both partners benefit from marriage, men on average have more power in the relationship. That is, men are in a position to 'get their way' more often and to achieve a higher degree of satisfaction of their preferences."). Thus, even when the law is gender neutral, like the Family and Medical Leave Act of 1993, 29 U.S.C. $\$ 2601$ et seq. (Supp. 1997), it is nevertheless likely to perpetuate gendered norms.

${ }^{72}$ As Professor Williams points out, current wage gap data "seriously underestimate the extent of women's marginalization in the workforce, because they compare the wage rates of full-time women with those of full-time men in an economy where more than half of mothers do not work full-time." Williams, supra note 69, at 274; see also Samuel Issacharoff \& Elyse Rosenblum, Women and the Workplace: Accommodating the Demands of Pregnancy, 94 Colum. L. Rev. 2154 (1994).

${ }^{73}$ Official records are not kept identifying those who come to the United States as mail order brides or pursuant to arranged marriages. Recent census data indicate large and growing numbers of spouses of U.S. citizens, and legal permanent residents, which would include members of both groups. See Table 26. Nonimmigrants admitted by class of admission: selected fiscal years 1985-2002, Fiscal Year 2002 Yearbook of Immigrant Statistics, available at http://uscis.gov/graphics/shared/aboutus/statistics/TEMP02yrbk/temp2002tables.pdf; Table 26. Nonimmigrants admitted by selected port of entry and region and country of citizenship, Fiscal Year 2003 Yearbook of Immigrant Statistics, available at http://uscis.gov/graphics/shared/aboutus/statistics/TEMP03yrbk/2003TEMP tables.pdf (last visited March 5, 2006). Some of these data include children of citizens and permanent residents. Experts estimate relatively small, but not insignificant, numbers of mail order brides, approximately 4,000 per year; Robert J. Scholes, The Mail Order Bride Industry and its Impact on U.S. Immigration available at http://uscis.gov/graphics/aboutus/repsstudies/Mobappa.htm (last visited October 29, 2005).

${ }^{74}$ Westfall, this volume (discussing property division). 
however, it would have to be shown that because of domestic violence in the relationship, it would be "unconscionable" to uphold the agreement. As Professor Brian Bix observes, the framework is elastic, and a judge could certainly find unconscionability under such circumstances. ${ }^{75}$ But this leaves the burden on the abused partner, almost always the woman, to articulate the objection and prove her claim. It is well known, moreover, that domestic violence takes place along a continuum, ranging from criminal assault, to murder, to verbal abuse. Sometimes the batterer, usually the husband, maintains control through subtle threats, establishing a pervasive, if unspecified, atmosphere of menace. Under the "unconscionability" framework of the PRINCIPLEs, it would be difficult to show why a wife should not be held to an agreement merely because she was afraid of her husband.

\section{Persistent Wage Gap}

As shown in U.S. Census data, the ratio of women's to men's median earnings has significantly increased in the last forty-two years. ${ }^{76}$ In 1960 , full-time women workers earned only $\$ .60$ for every dollar earned by full-time men workers. In 2002 , such women were earning $\$ .77$ for every dollar earned by such men.

This is not as good for women as it might appear, however. First, beçause fewer women than men are engaged in full-time paid work - in part, of course, because of their ongoing unpaid work in the home - women's income as a percentage of men's remains roughly constant. ${ }^{77}$ This is consistent with the disproportionate number of women living in poverty. As the Center on Hunger and Poverty at Brandeis University recently reported, femaleheaded households showed the highest levels of food insecurity and hunger in 2002, with 32 percent of such households experiencing food insecurity and 11 percent of such households experiencing hunger. ${ }^{78}$

Poverty grew in the United States in 2004, affecting approximately 12 percent of the population, mostly women and their children. ${ }^{79}$ Because of the ongoing gendered disparity of wealth and income in this country, as well as women's ongoing child care and elder care responsibilities, women remain disproportionately dependent on social safety nets. Moreover, since such safety nets are "hung low and full of holes in the United States," women remain economically dependent on men. To the extent that the Women's Convention focuses on the factors responsible for women's ongoing economic subordination, it shifts the frame created by the Principles. It situates the disputed agreement within the larger context of ongoing discrimination.

The Women's Convention would not necessarily protect women from such discrimination in this context, because itcould only do so by shifting the entire burden to the husband. Where the husband was neither responsible for such discrimination nor directly benefited from it, this would not be fair. Thus, for example, a male doctor divorcing a female nurse would not be considered responsible for the gendered wage disparity between doctors and

\footnotetext{
${ }^{75} \mathrm{Bix}$, this volume (discussing premarital and marital agreements).

${ }^{76}$ David Leonhardt, "Poverty Grew in 2004, While Income Failed to Rise for 5th Straight Year," NY TImes Aug 31, 2005 (citing recently released Census Bureau figures). Women's median income was $\$ 31,200$; men's median income was $\$ 40,800$.

${ }^{77}$ Id.

${ }^{78}$ Center on Hunger and Poverty available at http://www.centeronhunger.org/hunger/facts.html (last visited October $29,2005)$.

${ }^{79}$ Leonhardt, supra note 76.

80 U.S. Courts as Magnet, in Charles Baldwin et Al., International Dispute Resolution (2003).
} 
nurses. At the same time, however, this is not a gender-neutral scenario, and the incorporation of the Women's Convention would help decision makers avoid the mistake of treating it like one. Where an agreement involved a mail order bride or an arranged marriage, the Women's Convention'would be even more important, focusing the court on the global inequalities that are the backdrop to such agreements.

\section{B. How the Women's Convention Would Further the Principles}

The Women's Convention provides a useful and constructive framework for recognizing and reallocating the costs of ongoing gender discrimination. It begins by defining the phrase" "discrimination against women" to mean "any distinction, exclusion or restriction made on the basis of sex which has the effect or purpose of impairing or wullifying the recognition, enjoyment or exercișe by women... of human rights and fundamental freedoms in the political, economic, social, cultural, civil or any other field." 81 Article 2 of the Women's Convention further requires the State "[t]o take all appropriate measures, including legislation, to modify or abolish existing laws, regulations, customis and practices which constitute discrimination against women." 82 This effectively holds the State responsible for all discrimination on the basis of gender, whether through State policy or private prejudice. ${ }^{83}$ Thus, the Women's Convention imposes an affirmative obligation on the State to take whatever steps are necessary to counteract discrimination against women, especially with respect to women's rights within marriage. ${ }^{84}$

\section{The Economic Covenant and the Principles}

\section{A. Why the Economic Covenant?}

As noted in the Comment to Section 7.02, premarital agreements regarding property and maintenance are not binding on English courts and some Canadian courts. ${ }^{85}$ Rather, the court's "power to do economic justice at divorce" trumps. ${ }^{86}$ It is this basic notion of "economicjustice," absent not only from the Princip LEs but from American law in general, that it is so crucial here. Procedural requirements, set out in Section 7.04, roughly replicate procedural due process requirements under domestic law. ${ }^{87}$ These are similar to rights set out in the Civil Covenant. Section 7.04(3)(a) of the Principles which requires that the agreement be executed at least thirty days before the parties' marriage, roughly corresponds

${ }^{81}$ See Women's Convention, supra note 8 , at 16 (emphasis added).

82 Id.

${ }^{83}$ See Rebecca J. Cook, State Accountability Under the Convention on the Elimination of All Forms of Discrimination Against Women, in Human Rights of Women: National and International Perspectives 228, 236-38 (Rebecca J. Cook ed., 1994). Cf. Susan Moller Okin, Is Multiculturalism Bad for Women?, in Is Multiculturalism BAD fOR WoMEN?, supra note 67 at 7,22 (noting that "[t] he subordination of women is often informal and private.... At least as important to the development of self-respect and self-esteem is our place within our culture. And at least as pertinent to our capacity to question our social roles is whether our culture instills in us and forces on us particular social roles").

${ }^{84}$ Id. Art 16.1 (e), 1249 U.N.T.S. at 41. More States have taken reservations to Article 16 than to any other article in the Convention. Rebecca J. Cook, Reservations to the Convention on the Elimination of All Forms of Discrimination Against Women, 30 VA. J. INT'L L. 643, 702 (1990).

\footnotetext{
${ }^{85}$ Principles $\$ 7.02$.
}

${ }^{87}$ Principles $\$ 7.04$. See, e.g., John Nowak and Ronal Rotunda, Constitutional Law 593, et seq. (7th ed. 2004). 
to the "notice" requirement in the Civil Covenant. ${ }^{88}$ Similarly, Section 7.04(3)(b), requiring that both parties be advised to obtain independent counsel, roughly corresponds to a right to counsel. ${ }^{89}$ In striking contrast, the PrINCIPLEs have very little to say about substantive requirements. Indeed, unless there is either proof of "unconscionability" or an explicit finding of "substantial injustice," grounded in one of three carefully limited circumstances noted above, the agreement must be enforced. This is neither workable nor adequate. Nor would it be the result if the Civil Covenant were applied in this context.

\section{B. How the Economic Covenant Would Further the PrInCIPLES}

The substantive requirements set out in Section 7.05, discussing When Enforcement Would Work a Substantial Injustice, fall far short of both the rights set out in, the Economic Covenant and reflected in the English and Canadian conceptions of "economic justice." 90 As noted above, the Economic Covenant assures basic economic and social rights, including the right to health and the right to an adequate standard of living. ${ }^{91}$ Unlike the Civil Covenant, it has no counterpart in U.S. jurisprudence. ${ }^{92}$ Article 10 of the Economic Covenant addresses "family rights." ${ }^{.93}$ By affirming that States "recognize that ... [t] he widest possible protection and assistance should be accorded to the family, which is the natural and fundamental group unit of society, ${ }^{194}$ Article 10 establishes the scope of the State's duty. Considered in conjunction with Articles 2 and 3, which require States to "ensure the equal rights of men and women to the enjoyment of all economic, social and cultural rights," ${ }^{, 95}$ Article 10 can be understood as a powerful safeguard for economic rights during marriage and at its dissolution.

In addition to the minimal restrictions set out in the Principles, it could be argued that if the agreement exacerbates or creates economic inequalities between the parties, it should be barred - at least in those situations where the less well-off spouse would be unable to enjoy an "adequate standard of living" if the agreement were enforced. This is consistent with provisions in the PRINCIPLES governing alimony which treat "any significant disproportionality in income-earning capacity that evolved during the marriage as

${ }^{88}$ Principles $\$ 7.04(3)$ (a). See, e.g., Nowax AND Rotunda, supta note 98 , at $\$ 13.8$.
${ }^{89}$ Principles $\$ 7.04(3)$ (b). NowaK AND Rotunda, supta note 98 , at $\$ 11.6$.

${ }^{90}$ Principles $\$ 7.02$.

${ }^{91}$ Id. Art 11-12, 993 U.N.T.S. at 7-8. See also Asbjorn Eide \& Allan Rosas, Economic, Social, and Cultural Rights: A Universal Challenge, in Economic, Social and Cultural Rights 15, 17 (Asbjorn Eide, et al., eds., 1995) (viewing economic, social and cultural rights as raising "question[s] of income distribution" and "protection of vulnerable groups such as the poor"); Danilo Turk, The United Nations and the Realization of Economic, Social and Cultural Rights, in The Implementation of Economic and Social Rights: National International and Comparative.Aspects 95, 106-07 (Franz Matscher (ed.), 1991) (employing term "economic" as part of set of "economic, social and cultural rights" that guarantee minimum welfare system).

${ }^{92}$ Cf. Charles L. Black, Jr., Further Reflection on the Constitutional Justice of Livelihood, 86 CouvM. L. Rev. 1103, 1104-05 (1986) (arguing that economic rights can be grounded in Constitution). For a thoughtful analysis of the Supreme Court's resistance to economic rights, see Jonathan R. Macey, Some Causes and Consequences of the Bifurcated Treatment of Economic Rights and "Other" Rights Under the United States Constitution, in Economic Rights 141, 151-70 (Ellen Frankel Paul, et al. eds., 1992).

${ }^{93}$ Economic Covenant, supra note 9 , at 7.

94 Id.

95 Id. at 5 . Article 2 provides that "[t]he States Parties to the present Covenant undertake to guarantee that the rights enunciated in the present Covenant will be exercised without discrimination of kind as to race, colour, sex... or other status." Id. However, Article 2 appears to apply only to rights "recognized" in the Covenant. See MatThEw C. Craven, The International Covenant on Economic, Social and Cultural Rights: A Perspective on its Development 26 (1995). 
a marriage-caused loss and require[ing] payments to reduce it in accordance with the length of the marriage." 96 It is also consistent with well-established.norms, at least in some American jurisdictions, that refuse to enforce agreements where doing so.will leave one of the spouses destitute. ${ }^{97}$ Current law in the United States is mixed on this issue, reflecting the lack of consensus and the often incorrect assumption that women now have "equal opportunity". in the workforce. ${ }^{98}$

1 It could also be argued, however, that the Economic Covenant does not require such a result. Rather, the Economic Covenant imposes obligations on the State. Indeed, there are no readily available examples in which the Economic Covenant has been relied upon tó prevent enforcement of a separation agreement. ${ }^{99}$ This is not surprising. Most countries which have ratified the Economic Covenant, and which take it seriously, also have domestic legislation implementing it in specific contexts. This legislation may have been enacted pursuant to the State's ratification, reflecting the same cultural norms about a society's responsibility to its most vulnerable members that would lead a State to ratify the Economic Covenant. In some cases, there are additional national or regional human rights instruments, consistent with and supportive of the Economic Covenant, but more closely tailored to national or regional needs and circumstances. In Canada, for example, economic rights are more likely to be protected under the Canadian Charter of $\cdot$ Rights and Freedoms. ${ }^{100}$ Similarly, In the United Kingdom, economic rights are more likely to be protected under the European Social Charter. ${ }^{101}$ Such protection may well take the form of family law requiring "economic justice" to be taken into account at divorce, regardless of the parties' earlier intentions, as it is in England and Canada. ${ }^{102}$

\section{How the Incorporation of International Law Would Actually Work}

There are two basic ways in which countries deal with international treaties. ${ }^{103}$ In monist legal systems, such as that of The Netherlands, once human rights instruments are ratified, they are incorporated into domestic law. As part of domestic law, the substantive provisions of the instruments may be relied upon as substantive domestic law. In dualist legal systems, such as that of the United States, human rights instruments (as well as other international treaties) do not become part of domestic law until - and unless - domestic implementing legislation is enacted. This is further complicated in the United States by the doctrine of selfexecuting treaties. That is, certain treaties (such as friendship, commerce, and navigation treaties) are considered self-executing and no domestic legislation is required. ${ }^{104}$ Since none of the human rights treaties are self-executing, however, this does not change the

${ }^{96}$ Katherine T. Bartlett, Saving the Family from the Reformers, 31 U.C. DAvis L. Rev. 809, 847 (1998).

97 See, e.g., Button v. Bútton, 388 N.W.2d 546 (Wis. 1986) (refusing to enforce agreement on the ground that, under the circumstances, it would be unfair to enforce it at divorce).

${ }^{98}$ Women still earn only $\$ .77$ for every dollar men earn. See text accompanying n. 60-61.

99 But see StARK, supra note 24, at 136-43 (discussing CEDAW Comments on the Marital Property Regime in Kenya).

${ }^{100}$ Available at http://laws.justice.gc.ca/en/charter (last visited October 29, 2005).

${ }^{101}$ European Social Charter, entered into force Feb. 26, 1965, 529 U.N.T.S. 89.

102 See text accompanying note 57, supra.

${ }^{103}$ For a rigorous analysis of the ways in which several States have incorporated international treaty norms related to gender, see Ruth Rubio-Marin \& Martha Morgan, Constitutional Domestication of International Gender Norms, in Gender and Human Rights 113 (Karen Knop ed. 2004).

${ }^{104}$ Asakura v. City of Seattle, 265 U.S. 332 (1924). 
basic analysis here. Even in countries where domestic legislation is not legally required, moreover, as a practical matter it may be necessary. As Arthur Chaskalson, Chief Justice of the South African Supreme Court, recently explained, courts are ill-equipped to enforce broad statements of economic rights. ${ }^{105}$

Under this proposal, the specified human rights instruments would function like the international human rights instruments function in monist systems. In such systems, each State has the option of enacting implementing legislation. Human rights are not an issue in every enforcement action as agreements under the PrINCIPLrs. Consideration of human rights would only be triggered if either party made a good faith claim that enforcement in a particular case would in fact violate human rights under the cited instrument. Mail-order brides or women in arranged marriages may be able to avoid agreements that may not be "unconscionable" under traditional conceptions of equity. The notion of autonomous bargainers, implicit in such conceptions, may well be completely alien to such women. The burden would be on the party claiming a violation to establish it to the court's satisfaction.

In support of their arguments, aggrieved parties could rely on jurisprudence of the monitoring bodies, the.Committee on the Elimination of Discrimination Against Women and the Committee on Economic, Social and Cultural Rights, and, where available, decisions of other national courts and tribunals. Professor Elizabeth Scott asks whether an agreement that perpetuated existing inequalities would be stricken under this standard. ${ }^{106}$. Where such inequalities were so extreme, or the parties so poor, that enforcement would leave one without healthcare ${ }^{107}$ or an adequate standard of living, ${ }^{108}$ it could be challenged. But this is hardly the situation in most of the reported cases, as Professor John DeWitt Gregory has observed. ${ }^{109}$ Application of international law does not eliminate freedom of contract, of course. It simply limits it in a few egregious cases.

\section{Conclusion}

The incorporation of human rights law makes sense in this context because, it provides normative parameters conspicuously lacking in American jurisprudence. These are norms that support the security and well-being of those who need it most. As Professor Ellman. observes, such law is unnecessary when there is affection between the parties who recognize a complex range of rights and responsibilities flowing between them. ${ }^{110}$ Some of these, according to the PRINCIPLES, should survive the termination of the relationship. Which ones? Why? The Principles answer these questions piecemeal, seeking to articulate an inchoate national or local consensus while conceding that in fact such a consensus may not exist.

International human rights law, in contrast, articulates the rough global consensus regarding that which is owed to the most vulnerable. This is the international version of

\footnotetext{
${ }^{105}$ Arthur Chaskalson, Remarks at Columbia Law School (Nov. 3, 2004).

${ }^{106}$ Comments of Professor Mary Ann Glendon, Workshop on the Principles, Cambridge, Massachusetts (Oct. 16, 2004).

107 Economic Covenant, supra note 9 , at 8.

108 Id. at 7.

${ }^{109}$ Comments of Professor John DeWitt Gregory, Workshop on the Principles, Cambridge, Massachusetts (Oct. 16, 2004) (referring to the PrINciples as "the PRINCIPLEs for the rich and farnous," which resonated strongly for many of those at the Workshop).

110 Ellman, supra note 11 , at 700 .
} 
what Professor Mary Ann Glendon has referred to as the "sub-strata, the common norms that hold everything up." ${ }^{111}$ Our reluctance to ratify the human rights instruments reflects, in part, our continuing resistance to the idea that the vulnerable have a claim against society in general. This is grounded, in part, in our sometimes exaggerated deference to freedom of contract and autonomy. But as the PRINCIPLEs affirm elsewhere, we have long recognized that the vulnerable have claims against their families.

I am deeply grateful to Mary Ann Glendon and Robin Fretwell Wilson for organizing the Harvard Workshop and for inviting me to participate, and to the other participants for their thoughtful presentations. The questions raised by Brian Bix, John DeWitt Gregory, Marsha Garrison, and Elizabeth Scott were particularly helpful. Warm thanks to Betty Black Leonardo for her skillful preparation of the manuscript.

${ }^{111}$ Comments of Professor Mary Ann Glendon, Workshop on PRINCIPLES, Cambridge, Massachusetts (Oct. 16, 2004). 